\title{
APPLICATION OF LEARNING TECHNOLOGY THROUGH THE EXPERIMENT OF TWO FASA INVERTER TO HELP THE HUMAN BODY AND DETERMINE THE INPUT AND OUTPUT POWER
}

\author{
Puji Hariati Winigsih ${ }^{1}$, Handoyo Saputro ${ }^{2}$, Astuti Wijayanti ${ }^{3}$, Ayu Fitri Amalia ${ }^{4}$ \\ \{pujihw@ustjogja.ac.id ${ }^{1}$, hansputra@yahoo.com², astuti.wijayanti@ustjogja.ac.id ${ }^{3}$ \} \\ Physics Education Department of Graduate Program Sarjanawiyata Tamansiswa \\ University, Tuntungan, Jl. Batikan, UH.III/1043, Yogyakarta 55157, Indonesia ${ }^{1,2}$, Science \\ Education Department of Graduate Program Sarjanawiyata Tamansiswa University, \\ Tuntungan, Jl. Batikan, UH.III/1043, Yogyakarta 55157, Indonesia ${ }^{3}$
}

\begin{abstract}
Physical experiments have a very important role in the development of science. Due to achieve that, it could be started by increasing the creativity of educators in innovating with the methods, models and learning media used. Research has been conducted with the aim of making a two phase phase inverter media to induce the human body and determine its input and output power. Method in this research was experiment. Tools and materials used include 3 Volts of inverter circuit, powerbank and finger lights. Data collection techniques by determining input and output power. Data were analyzed by using Chi-Square. The results obtained in the form of a two phase inverter experiments. Average input power $(3.00 \pm 0.005)$ Watt, output power after induction $(2,250 \pm 0.005)$ Watt and Efficiency $(9.16 \pm 0.005)$. It appeares that there is an increase in output power up to 3 times of input power. This increase in output power can be enlarged as desired by adding windings to the transformer.
\end{abstract}

Keywords: experiments, two phase inverter, induction, human body.

\section{Introduction}

The development of Information and Technology in today's global era has had an impact on every line of life, not least the education field. Education is required to follow the development of the global era while maintaining the main mission of the intellectual life of the nation [1]. If physics is seen as an empirical science (and that is what it is), then physics learning should begin with or involves observing the phenomena or natural phenomena associated with the physical learning materials to be taught, as well as the physical nature of the product, process and attitude [2]. To achieve them, it can begin in the learning process. Educators need to routinely make learning innovations in the process of teaching and learning activities. Learning innovation can be done either from the methods, models, or learning media used [3].

Learning innovation can be a teaching aids and the existence of teaching aids can facilitate educators in delivering the material [4]. The use of instructional media such as teaching aids in teaching methods are two things that are interrelated. This linkage serves to 
facilitate the transfer of knowledge (material) to fit the goals achieved in learning [2]. The benefits of props that can negate the barriers of space and time dimensions. Examples of teaching aids that can be used in learning are a lot, some are based on IT, local materials and / environment and others.

In the previous research mentioned that the development of teaching aids based microcontroller nodeMCU on Newton's law material showed positive results with excellent product quality and response [5]. In addition to play a role in realizing effective learning, teaching aids also play a role to stimulate the imagination of students and give a deep impression during the learning process. Teaching and learning process begins by preparing learning objectives, materials, teaching methods, learning media, and evaluation. Therefore, in preparing the learning media must be creative and innovative for example by making simple teaching aids which can explain material about induction. There are still many physics concepts that can be applied to objects that are not widely known by physics students. For example, the inverter can induce the human body (not just using metal) and can be used as a protective tool of crime.

It is known that cells in the human body numbering more than one trillion that each of them have an electric charge of $90 \mathrm{mV}$ with a positive charge outside the cell membrane and a negative charge in it. If the series can be made in electrical problems between one cell with another cell then the human body has a very large potential in generating electrical voltage. For example, to produce a voltage of $220 \mathrm{~V}$ (household electrical voltage) required a series relations of 2500 cell only, while the human body contains more than 1 trillion cells. Such a thing can also be done by using a human body conductor with the help of electronic devices (inverters).

Power inverter or usually referred to as an inverter is a circuit or electronic device that can convert a direct electric current (DC) to an alternating electrical current (AC) at the voltage and frequency required in accordance with the design of the circuit [6].

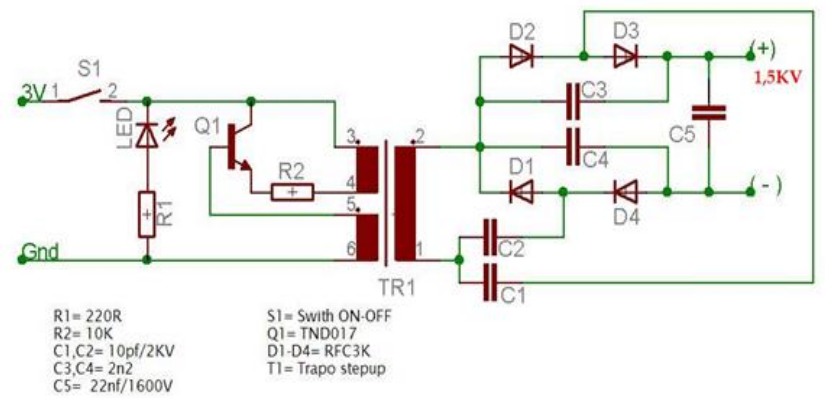

Fig. 1. Simple two-phase inverter circuit.

In Figure 1, the two-phase Inverter circuit is indicated by two diodes [7]. This tool will be used to describe Induction. Induction is a process of electricity generation (electric) in closed circulation by magnetic current (motion) through rotary motion. In physics is also known the term induction of charge is the provision of a charge by closing the object charged with a neutral object [8]. The induction process can also produce an electric current usually using a generator (metal) tool, but in this study will be used as a human body carrier.

The aim of this research was to make two-phase inverter media to induce human body and determine input and output power. 


\section{Methods}

This research was using experimental method. Tools and materials included 3 Volt and 9 Volt inverter circuit, powerbank, finger lamp, and multimeter. Design the two phase inverter as based on the circuit in Figure 1. The tool was used for induction experiments in the human body with the research flow in Figure 2. Data collection techniques by determining the input and output power after induction occurs.

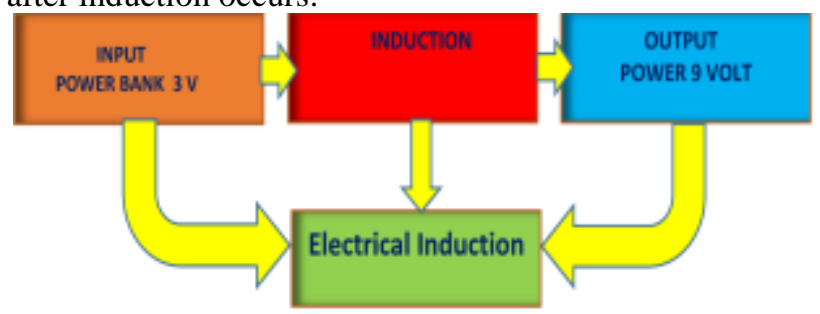

Fig. 2. The research flow.

The data were collected 10 times at each time variation $(0.25,0.30,0.35,0.40,0.45,1.00$, 1.15) hours. From the results of the measurement was then calculated the efficiency using equation 1. The data were then analyzed using Chi-Square.

$$
\eta=\frac{P_{\text {in }}}{P_{\text {out }}} \times 100 \%
$$

\section{Discussions}

The results obtained in the design of experimental tools as a medium of physics learning is considered useful so that it can be implemented as a consideration to support the development of instructional media planned especially in physics lab. This process is also associated with the pattern of creative learning development and adjustments to the use of learning theories that can be applied in lectures and research results to complement the process of program design.

In this study using learning devices through physics experiments have several stages: (a) The exploration of practicum kits, among others, by designing creative and innovative lab tools and able to design practicum activities by utilizing the surrounding environment (human body); (b) Kind of practicum for the same concept with new creative ideas by utilizing secondhand items or by making a series of modifications from existing equipment; (c) Practical design in physics learning, unique in developing practice lab.

Obtained design results of two-phase inverter experiments, as shown in Figure 3. The resulting device is then used to describe the induction by conducting the human body as shown in Figure 3. Induction of this research is a process of electric charge transfer (two phase inverter) due to other objects that are electrically charged nearby (human body). the electrical induction process of charge produced is always opposite to the charge of the induced object, for example if the induced object is positively charged then the charge of the induced object is negative. 


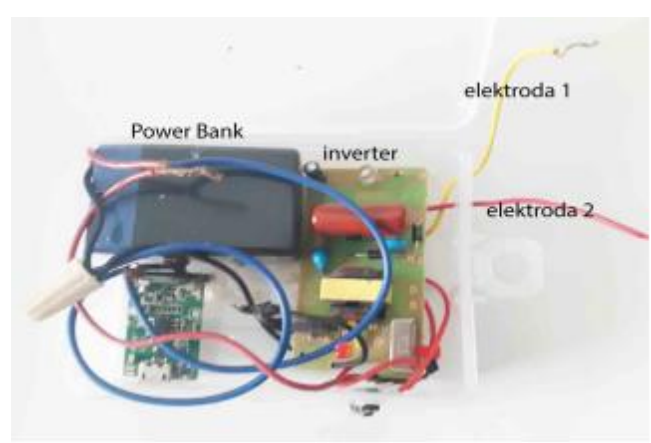

Fig. 3. Two-phase inverter induction experiments.

In Figure 4, a two-phase inverter is installed at the waist, so it is easy and practical to use. Then there is a cable connected to the ground that is placed under the footwear (Shoes / sandals), the purpose is that the device does not shock to the user's body. To know the amount of voltage or power generated both input and output, then the measurement is done by using a multimeter.

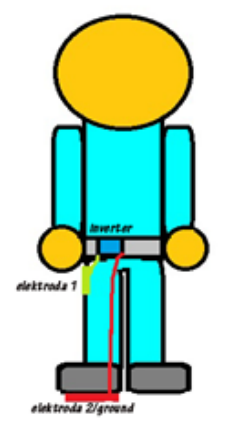

Fig. 4. Illustration of electric induction through the delivery of the human body.

From the experimental results, it is known that the tool can produce output power with an average of 3 times of input power (3.0 Watt to $9.16 \mathrm{Watt}$ ), as shown in Table 1. The increase in electrical power can be increased in value according to our wishes that is by adding windings to the transformer.

Table 1. Output data of input and output power.

\begin{tabular}{cccccc}
\hline No & & $\mathrm{I}$ & & & \\
& $\mathrm{t}(\mathrm{jam})$ & $(\mathrm{mA})$ & $\mathrm{P}_{\text {input }}(\mathrm{Watt})$ & $\mathrm{P}_{\text {output }}(\mathrm{Watt})$ & $\eta$ \\
\hline 1. & 0.25 & 0.24 & $(2.90 \pm 0.005)$ & $(8.90 \pm 0.005)$ & $(0.24 \pm 0.005)$ \\
\hline 2. & 0.30 & 0.25 & $(2.80 \pm 0.005)$ & $(9.00 \pm 0.005)$ & $(0.25 \pm 0.005)$ \\
\hline 3. & 0.45 & 0.24 & $(3.00 \pm 0.005)$ & $(9.20 \pm 0.005)$ & $(0.25 \pm 0.005)$ \\
\hline 4. & 1.00 & 0.26 & $(2.90 \pm 0.005)$ & $(8.80 \pm 0.005)$ & $(0.24 \pm 0.005)$ \\
\hline 5. & 1.15 & 0.25 & $(3.20 \pm 0.005)$ & $(9.90 \pm 0.005)$ & $(0.25 \pm 0.005)$ \\
\hline
\end{tabular}


Graph of input and output power at the time variation shown in Figures 5 and 6. Input power is power before induction occurs. The output power is power after induction occurs.

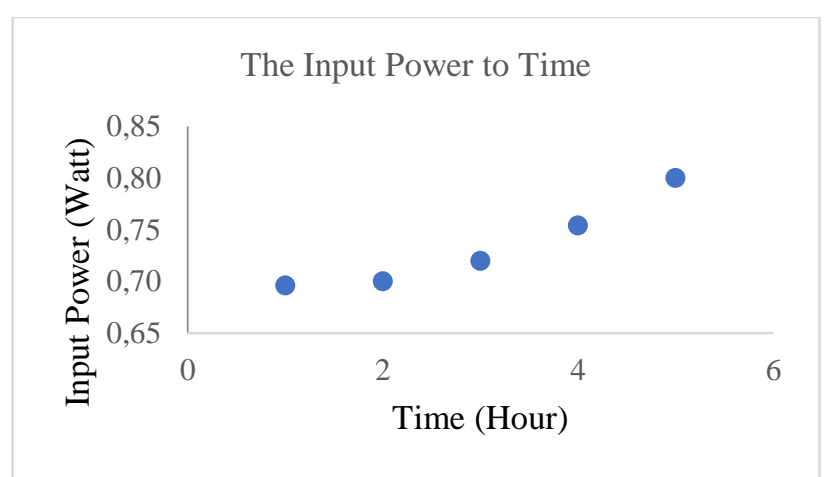

Fig. 5. Graph of the input power to time.

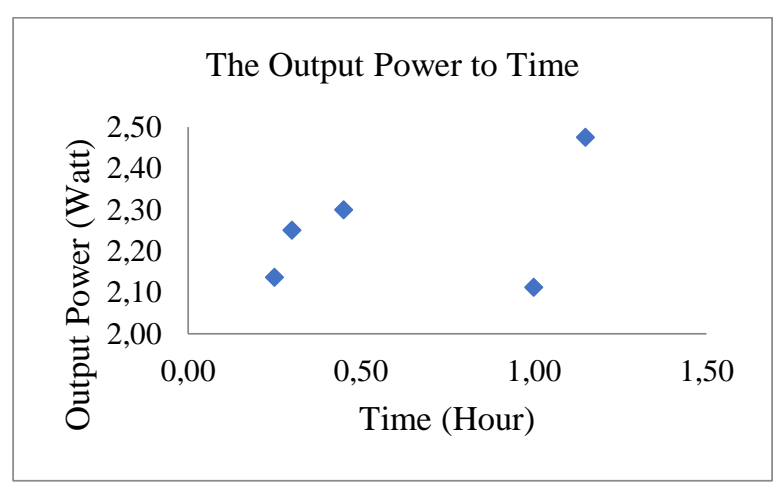

Fig. 6. Graph of the otput power to time.

The efficiency of a transformer can be defined as a comparison between the output power $\left(\mathrm{P}_{\text {out }}\right)$ and the input power $\left(\mathrm{P}_{\text {in }}\right)$. Using equation 1 , it obtains the graph of the relationship between the efficiency to time (Figure 7).

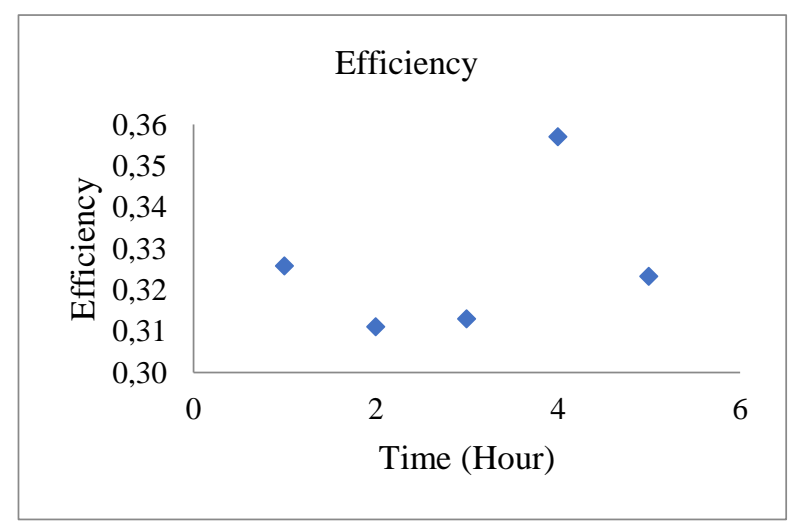

Fig. 6. Graph of eficiency. 


\section{Conclusions}

The physics learning media has been created in the form of a two-phase inventer experimental instrument in the induction material. This tool is capable of generating enormous power with an average of 3 times of the input power depending on the number of turns. Known there is an increase in output power is large enough that 3 times of the input power. The output power can be increased in size as desired.

Acknowledments. This research is funded by LP3M of Sarjanawiyata Tamansiswa University, therefore the author of the message many thanks to the party for his trust.

\section{References}

[1] Soedijarto, "Profesional Guru (Pendidik) dalam Era Globalisasi, Implikasi, Peluang, dan Tantangannya," 2013. [Online]. Available: www.ispi.or.id.

[2] Sutrisno, "Pengembangan alat peraga untuk pembelajaran fisika," pp. 1-21, 2006.

[3] F. Muchlis and M. Toifur, "Rancang Bangun Prototype Media Pembelajaran Fisika Berbasis Micro Controller NodeMCU," vol. 4, no. 1, pp. 12-17, 2017.

[4] A. I. M. Kuliah, "Handout Mata Kuliah Media Pembelajaran Matematika ( Mt .../ 2 Sks ) Program Depag 2008,” 2008.

[5] S. Rochaeni, "Pengembangan Alat Peraga Fisika Sma Materi Hukum Newton Dan Aplikasinya Snf2015-Ii-71 Snf2015-Ii-72,” vol. IV, pp. 71-76, 2015.

[6] I. S. Wardhana, Karnoto, and A. Warsito, "Perancangan Inverter Push Pull Resonan Paralel pada Aplikasi Fotovoltaik,” Transient, pp. 1-6, 2012.

[7] M. Induksi, S. Fasa, and B. Dc, ““” Desain dan Analisa Bidirectional Inverter Sebagai Penggerak," vol. 3, no. 1, pp. 1-8, 2016.

[8] A. . Fallis, University Physics with Modern Physics, vol. 53, no. 9. 2013. 